\title{
Beyond the volcanic crisis: co-governance of risk in Montserrat
}

Emily Wilkinson

\begin{abstract}
Disaster risk governance is concerned with how institutions change in response to perturbations or, conversely, are able to remain static for long periods of time. In Montserrat, the volcanic eruption in 1995 produced unprecedented challenges for both local government authorities and the UK Government. The sharp and sustained rise in the level of volcanic risk combined with an inadequate response from UK and local authorities prompted a shift in governance arrangements, and when levels of risk declined these new configurations did not go back to their pre-crisis state.

This paper focuses on one aspect of this governance transition: the relationship between the local Montserratian government and the UK government. Before the eruption Montserrat enjoyed high levels of political and fiscal independence from the UK in disaster risk management and other investment decisions, but the volcanic crisis highlighted low levels of capacity and the inherent instability in this system. A new co-governance regime was established after the crisis, characterised by greater UK intervention in local investment decisions and some loss of political sovereignty. On the other hand, Montserrat has become more integrated in regional and international disaster risk governance systems, and today the division of local and central responsibilities for different aspects of disaster risk management is much clearer than before the volcanic crisis.

This paper demonstrates how disasters can create spaces for existing risk governance systems to be questioned and modified. The volcanic crisis led to a reconsideration of responsibilities and risk management practices by both Montserratian and UK authorities, and initiated a process of transformation in land-use and development planning that has substantially reduced levels of volcanic risk on the island. However, these benefits have to be weighed against loss of livelihoods for a significant proportion of the population and considerable social upheaval. Critical to the success of this new development model is the need for vertical coherence and dialogue between different stakeholders. Montserrat and UK risk governance systems are more integrated now, but unless communities are engaged in risk management decisions, Montserrat's low- risk development model could come unstuck. Small islands with large risks can learn a lot from the Montserrat experience.
\end{abstract}

Keywords: Disaster risk management; Volcano; Montserrat; Governance; Risk tolerance

\section{Background}

A disaster risk governance system comprises a complex web of actors and networks involved in formulating and implementing polices to manage disaster risk, institutional arrangements that determine the relationships, roles and responsibilities of these actors, coordinating mechanisms and political culture, including different perceptions of risk (Renn 2008; Wilkinson 2013). The system is therefore characterised by a number of elements

Correspondence: e.wilkinson@odi.org.uk

Overseas Development Institute, Climate and Environment Programme, 203 Blackfriars Road, London SE1 8NJ, UK of interaction such as stakeholder participation in policies to reduce risk (Pelling 2011).

This paper is concerned with multiple levels of risk governance and (a) whether crisis leads to changes in the system; (b) the nature of the shift (key aspects of the system that are altered); and (c) the change process. This is assessed in the context of Montserrat in the British West Indies, where a long-duration volcanic crisis in the 1990s highlighted internal contradictions inherent in the broader system of governance. Other volcanic eruptions in the eastern Caribbean have resulted in greater loss of life than the 1995-1997 eruption of Soufrière Hills Volcano-most 
notably the 1902 eruption of Mont Pelée in Martinique, which killed 29,000 people (Tanguy 1994) - but the Montserrat volcanic crisis has attracted special interest from natural and social scientists alike because of the unpredictable and incremental escalation of volcanic activity, coupled with vulnerability and exposure characteristics found only on small islands.

A series of forced evacuations and delineation of risk zones in Montserrat avoided the mass casualties of Martinique, but on 25 June 1997, 19 people returning to the exclusion zone were killed by pyroclastic flows (see Figure 1). Two months later pyroclastic flows engulfed the capital, Plymouth, putting an end to discussions on whether the port and other major facilities could be used for the foreseeable future. Before these tragic events the Government of Montserrat and the UK Government had been struggling to manage a crisis for which they were relatively unprepared and when rehabilitation and reconstruction began, they continued to face difficulties and public criticism.

The purpose of this paper is not to provide a summary of events, or attempt to evaluate the effectiveness of collective responses to the volcanic crisis. Numerous reports and papers have been commissioned and written on the events and decisions taken by UK and Montserrat authorities, each presenting a view of what went wrong (see, for example, Clay et al. 1999; Donovan et al. 2012; Kokelaar 2002). More recently, studies have focussed on post-disaster reconstruction and the UK government's performance in promoting long-term development on the island (ICAI 2013; Sword-Daniels et al. 2013). Rather, the paper takes a longer term view of changes in disaster risk governance, analysing the critical shifts that occurred in response to an extreme event, as well as the change processes themselves (for a summary of key disaster risk governance events see Additional file 1).

\section{Conceptual framework}

Concepts of 'systems' and 'scale' are used to study the nature of changes in response to perturbations. These draw on the socio-economic systems, resilience and natural resource governance literature. 'Scale' is defined as the spatial, temporal, quantitative, or analytical dimensions used to measure and study any phenomenon (Gibson et al. 2000). This paper focusses

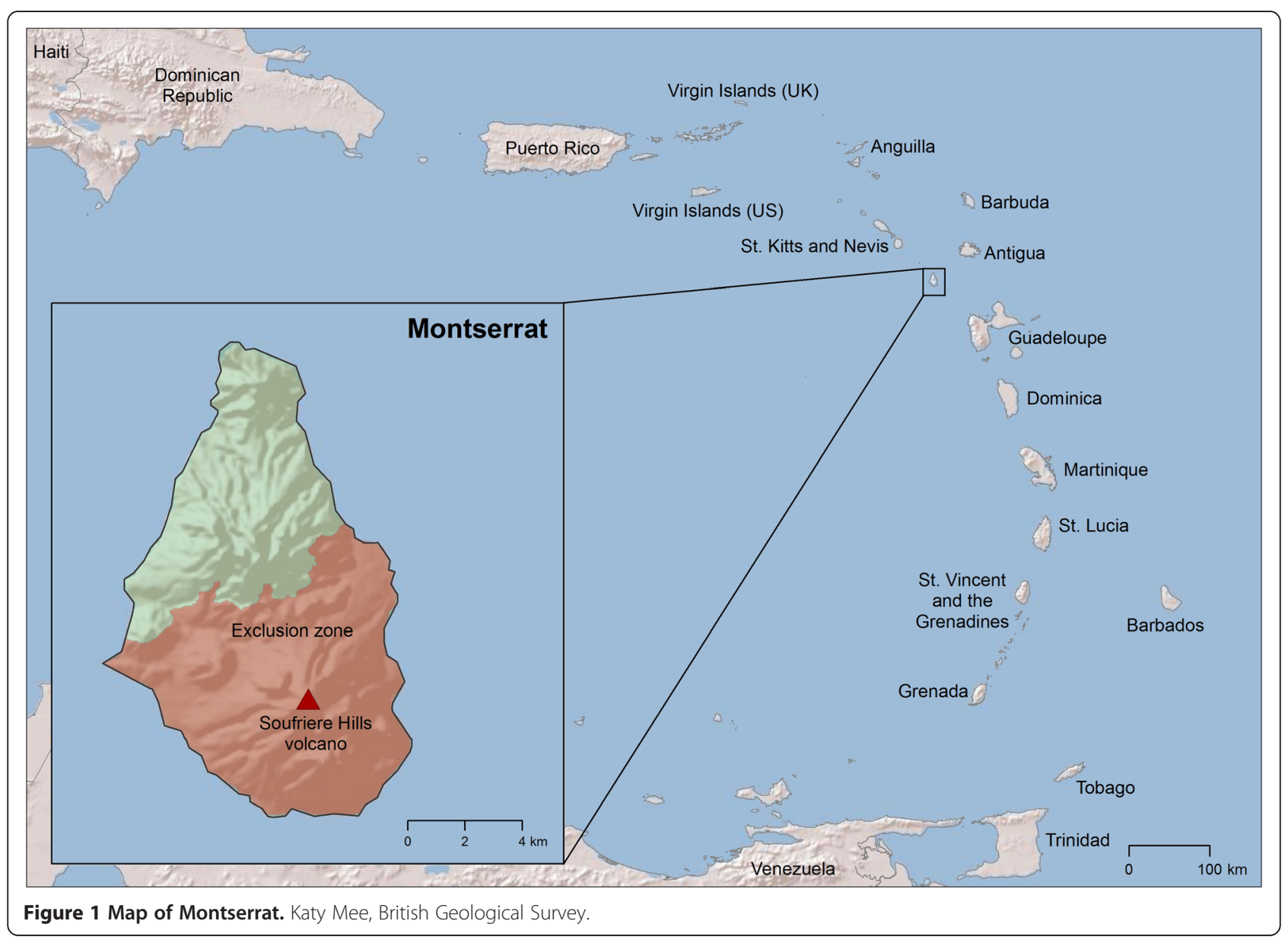


on two scales: the jurisdictional scale, which can be divided into different bounded and organised political units, with linkages between them; and the temporal scale, which can be divided into different 'time frames' related to rates, durations, or frequencies (Ostrom et al. 1999). Effective disaster risk management (DRM) depends on the cooperation of international, national, regional and local institutions across temporal and jurisdictional and geographical scales, so understanding these interactions is critical.

Within the jurisdictional scale, the vertical power relationships between local and central political units are of particular interest. Building on work by Claudia Pahl-Wostl (2009) on multi-level learning processes and adaptation, two key aspects of vertical governance dialectics can be identified: (a) dispersion of decision-making authority and (b) vertical coherence.

(a) The dispersion of decision-making authority refers to the authority of different centres of decision making that are formally independent of each other (Ostrom, 1997; McGinnis 2000; Heinelt 2002). Local governments are thought to require autonomy from higher levels of government so that they can define their own priorities and implement DRM measures without too much interference, and thus gain credibility and trust from their citizens; both of which have proven critical for disaster risk management (Wilkinson 2012). However, this kind of autonomous, inclusive style of governance is not the modus operandi of most local governments. This paper focusses on the political and fiscal autonomy of the Montserrat government to develop its own risk management policies, as well as its capacity to do so. It discusses the evolution of co-governance arrangements through which UK authorities and the Montserrat government jointly make decisions to manage exposure to volcanic risk.

(b)Vertical coherence is concerned with the division of roles and responsibilities for risk management between different political units, from local government to tiers higher up the scale - including provincial governments (or states in federal systems of governance), national government and regional authorities like the European Union (EU). Incoherence in service delivery often occurs because of poorly defined and overlapping mandates (resulting in omission and/ or replication in service delivery), overly complex structures (Pahl-Wostl 2009), capacity constraints and unfunded mandates (Posner 1998), as well as centrist and paternalistic tendencies in public administration systems (Wilkinson 2012); all of which can constrain progress on managing disaster risk. Hence, an alignment of interests between governance scales can help to promote more effective DRM. This includes not only the participation of actors from one level in decision-making processes at another but also institutions and knowledge produced at one level influencing processes at another (Pahl-Wostl 2009).

Particularly critical for DRM is the alignment of risk perceptions across scales of governance through bi-directional process (Slovic 1987). Different people and cultures respond to disaster risk differently (Gaillard 2008; Heijmans 2001; Paton et al. 2001; Paton et al. 2010), and in the context of volcanic hazards, proximity to the hazard (Gregg et al. 2004), living memory of an eruption and level of impact (Paton et al. 2001) all shape risk perceptions amongst individuals and groups. Even if risk perception is high, people may still put concerns about convenience and living costs ahead of their desire to lessen their exposure (Gaillard 2008). This suggests that the idea of an acceptable level of risk is inappropriate. Rather, people do not accept risks but tolerate them to secure certain benefits (Pidgeon et al. 1992; Simmons and Walker 1999). The values underlying any notion of tolerable risk may not be shared by everyone; in fact much research on risk analysis and societal reactions to different threats highlights the differences between institutional responses such as regulation and public responses (Barnes 2002). In particular, disaster events can result in the creation of new official rules to control risk that minimise exposure - for example through the creation of exclusion zones and resettlement policies - but these values may not be shared by those that live in exposed areas and whom are to be resettled. Dialogue and negotiation between authorities and communities is therefore required to reach more sustainable solutions (Haynes et al. 2008).

The analysis of the disaster risk governance system in this paper draws heavily on resilience thinking, and in particular resilience frameworks that emphasise the capacity of a system to respond to shocks and stresses in different ways - such as by coping, adapting and transforming (Bené et al. 2012; Cutter et al. 2008; Pelling 2011). Disaster risk governance systems are highly sensitive to rates, durations and frequencies of disaster events and changes in the system often occur as a result of these events as well as in response to other external pressures. The feedback processes are however nonlinear and unpredictable (Ramalingam et al. 2008).

Notwithstanding their idiosyncrasies, volcanic eruptions can be characterised in terms of their spatial and temporal dimensions: they are often slow onset and long duration event that allow for changes in policy and behaviour while the event is still unfolding. It is usually possible to identify sharp increases in the level of risk, resulting in crisis period(s) for affected populations and 
decision-makers. Hence volcanic disaster risk can be considered to have three temporal phases within which feedback processes occur, with accompanying options for institutional learning and collective action:

(i.) Pre-crisis period, in which action may be taken to mitigate existing and anticipate future risk, such as land-use planning, retrofitting roofs, the development and enforcement of building codes, education and training programmes. Land-use planning is a prospective tool that can be used to prevent or limit construction in unsafe areas, while relocation and re-zoning of space is a corrective tool to reduce existing exposure to hazards. Education related to building practices that reduce ash entry into homes is a risk management activity that anticipates and reduces risk in the future, while training on early warning systems manages current levels of risk by encouraging evacuations and reducing loss of life.

(ii.) Crisis period, which we can sub-divide into: a) start of the eruption and potentially long period of unrest (often characterised by seismic activity), which can be treated as a preparedness phase; and b) heightening of the crisis, usually initiated by an eruption, prompting emergency response activities to reduce negative impacts on people, such as food aid and shelter provision. These sub-phases vary widely across settings however and some volcanoes may do (a) and not (b), while some have (b) with no (a).

(iii.) Post-crisis period, characterised by short- and longer-term recovery measures (the first of which may commence during the crisis period) to restore livelihoods and infrastructure as well as control future risk and promote sustainability (Alexander 2002; Tierney 2012). These corrective and prospective risk reduction measures are more likely to occur in the post-crisis period than before an event has occurred as disasters highlight previous failures and can act as catalysts for policy reform (Birkland 2006).

These three temporal phases may overlap if time between subsequent eruptions is short. Also, the shift from one state to another is not necessarily demarcated by the volcanic hazards themselves: there may still be low-impact hazards occurring in in the post-crisis period; and changes in the level of risk might also be caused by non-volcanic events that alter the level of exposure or vulnerability to different hazards. Nor do the phases identified above represent a cycle in the social system (from stability-to crisis-returning to a stable state). Indeed, the concept of a 'disaster cycle' has been heavily criticised by social scientists for representing disasters as temporary interruptions of a linear development process and governance systems, after which society returns to normal (Christoplos et al. 2001; Hewitt 1983;
Twigg 2004). Governance systems do sometimes return to pre-crisis states, demonstrating the stability or persistence of institutions in the face of extreme social events (Schreyögg and Sydow 2010). However, more often in environmental and social systems, regime changes occur following significant perturbations, whereby the system moves to another stable state and sometimes this regime shift is irreversible (Whitten et al. 2012). Similarly, for disaster risk governance systems, we can expect disasters to alter components of the system, at least temporarily whether perturbations are low-intensity but frequent or singular, high-intensity events. Changes in the disaster risk governance system during and following a protracted crisis can therefore be characterised in terms of their stability, from temporary alterations to permanent, irreversible shifts.

Another aspect of the change process is the extent to which the governance system is altered by the event whether it undergoes fundamental changes or not. Levels of organisational change are described in the literature on adaptation and resilience, where differences are drawn between single and double-loop (and sometimes even tripleloop) learning; incremental and radical reform; transitions and transformations (Pelling 2011). According to Mark Pelling (2011: 74) transitions or incremental changes can be seen when 'the aims and practices of geographically or sectorally-bound activities push but do not overturn established political regimes', while transformation 'is an extreme case where profound change alters the distribution of rights and responsibilities and visions of development across society'. Similarly, while single-loop learning describes the detection of an error and correction without questioning the underlying values of the system, doubleloop learning occurs 'when mismatches are corrected by first examining and altering the governing variables and then the actions' (Argyris 1999: 68).

The nature of disaster risk governance shifts and change processes described above can be summarised in a matrix (see Table 1) and form the conceptual basis for analysing institutional change in Montserrat. The unique cogovernance characteristics in Montserrat and other UK overseas territories present a number of challenges to studying institutional change of any sort. Institutions and individuals interact in ways that are very different to other governance settings $\mathrm{s}^{\mathrm{a}}$, making generalisations or lesson drawing about drivers of change particularly difficult. However, in focussing on the dynamics of vertical governance, direct comparisons can be made to governance arrangements in other contexts, including in federal governance systems such as Mexico and India, decentralised systems such as those found elsewhere in the Caribbean and other multi-layered systems of governance, such as the European Union. Conclusions are tentative and caution must be applied in making generalisations, but the 


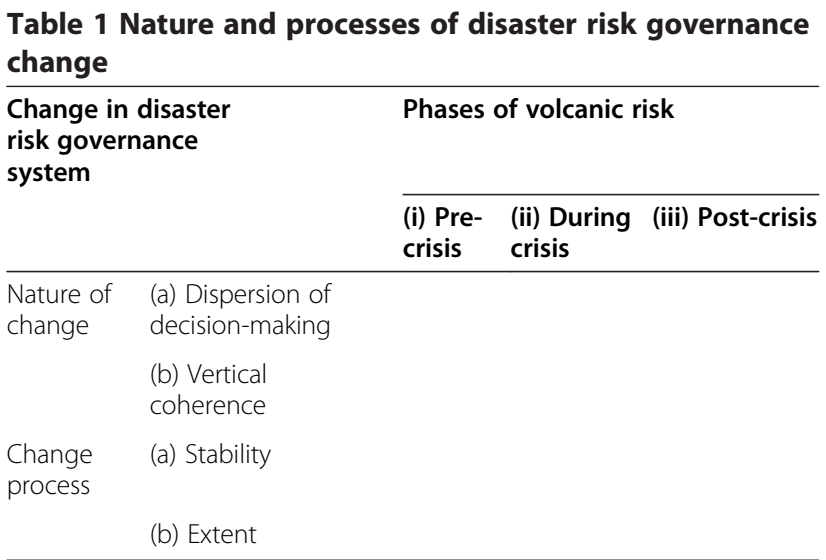

Montserrat case is instructive of a more permanent cogovernance transition that can occur following a volcanic crisis.

\section{Methods}

The analysis of vertical governance arrangements in Montserrat presented below is based on qualitative primary data collected through a 'forensic' workshop ${ }^{b}$ held in September 2012 with 70 participants representing five stakeholder groups: scientists, UK government officials, Montserrat government officials (including disaster managers), regional agency staff and community representatives. The aim was to explore components of resilience during and after the volcanic crisis as well as internal and external factors that have undermined it. Moderated focus group discussions on key events, tipping points and phases of change were held and recorded. In addition, 16 semistructured interviews were conducted with local and UK government officials and community leaders. Workshop and interview recordings were transcribed and coded and analysed using Atlas-ti software.

The coding categories were derived from the conceptual framework to capture data on: (i) risk management policies and key decisions taken during different time periods (before, during and after the crisis); (ii) roles and responsibilities of different actors for DRM activities; (iv) relationships between UK and local government authorities; and (v) public perceptions of government decisions on risk management policies (both UK and local). Interview and focus group data was also coded for issues of (vi) risk perception, (vii) trust and (viii) participation. Data was triangulated across the five stakeholder groups and with secondary literature, to help explain differences in judgements about decisions taken by local and UK authorities. Tensions arose as roles and responsibilities changed during and after the crisis and these are highlighted, as are the contrasting views of citizens and formal institutions on levels of tolerable risk.
It is important to point out that primary data was collected from the focus group discussions and interviews to supplement existing data and analysis of the Montserrat crisis and recovery processes. This explains the very limited number of interviews. While this has its limitations, the research team felt that governance during the crisis and its immediate aftermath had already been studied in depth, albeit from the perspective of science-policy interface (see, for example, Donovan et al. 2012; Donovan and Oppenheimer 2013). Further data was therefore collected to complement this and bring it up to date, situating the analysis of risk governance within broader decisions about development and the future of the island.

\section{Disaster risk governance in Montserrat - an unstable state}

On the 18th July 1995, the Soufrière Hills Volcano became active after a long period of dormancy. Approximately 6,000 people were evacuated from the capital Plymouth and nearby towns to temporary shelters. They returned to their homes, were evacuated again, and on 3rd April 1996 Plymouth was evacuated for the last time. Approximately 1,300 people were housed in temporary public shelters, which suffered from overcrowding, lack of privacy, poor sanitation and lack of access to good nutrition. Many Montserratians left the island, supported by UK resettlement packages, family and friends. By 2001, the population of Montserrat had dropped by $60 \%$, from 11,314 in 1991 to 4,491 in 2001 (CARICOM 2009). For those that stayed, some were still in shelters three years after the eruption. Those that decided to stay and resettle in the north of the island, which is much drier and less fertile than the south and more exposed to hurricanes and flooding, faced severe challenges in re-establishing their livelihoods (Rozdilsky 2001).

Re-settlement in the south meanwhile has been controlled and in some areas prohibited. Exclusion zones have been set up to control access to areas close to the volcano according to the level of volcanic activity (see Figure 2). These and other major risk management decisions are listed in Annex 1. The governance arrangements and relationships shaping these decisions and collective responses to volcanic risk are discussed below.

\section{Risk governance before the volcanic crisis}

Governance arrangements in UK overseas territories are unique because of their colonial history, although they have some similarities to structures found in decentralised systems of governance elsewhere. Local governments have autonomy over day-to-day decision-making and planning with regard to social and economic policy, receiving some budget support to do so, but defer to central government over decisions regarding internal security and defence. This includes emergency management functions, if the capacity of local government to 


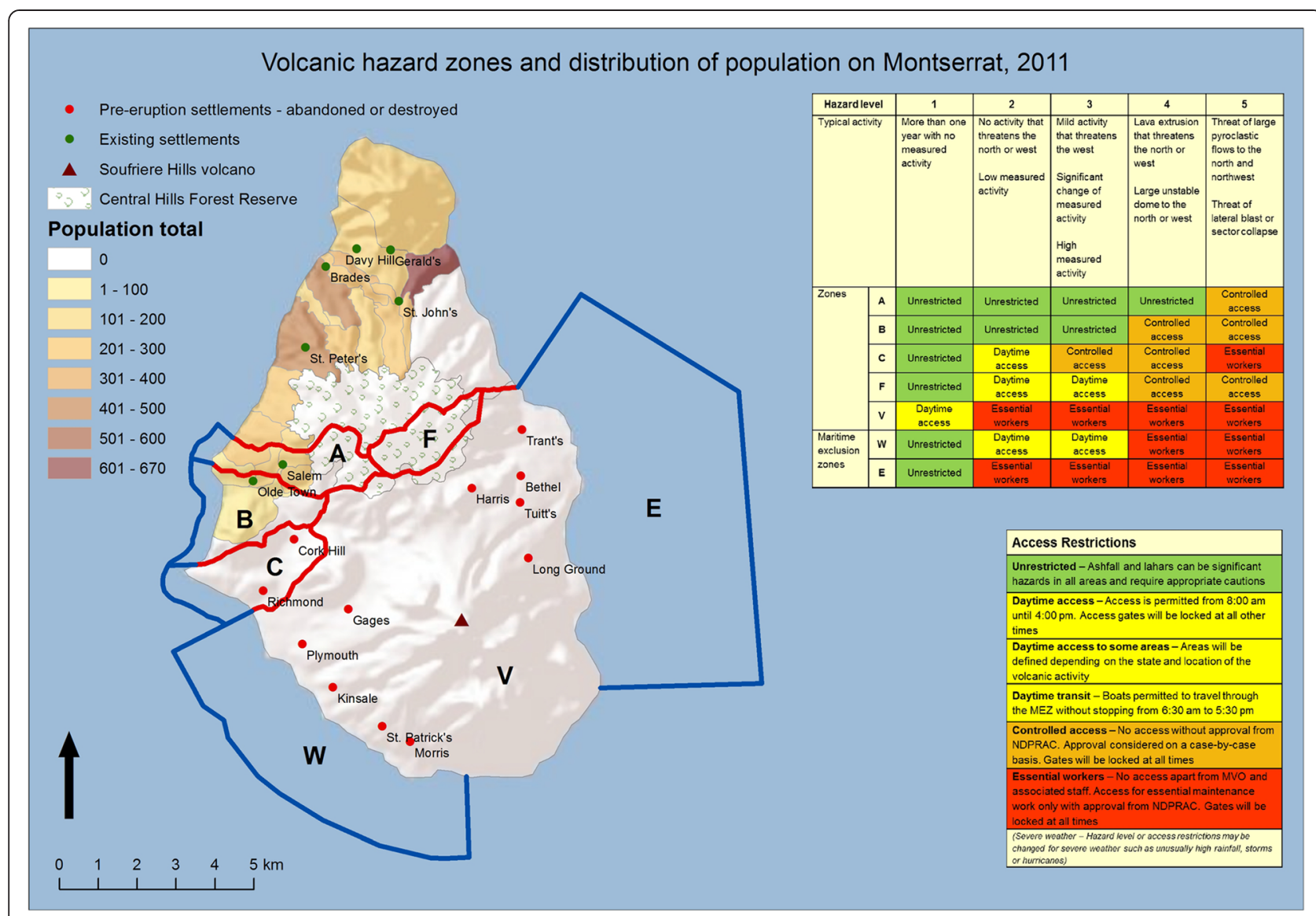

Figure 2 Map of exclusion zones, settlements in 2011 and pre-eruption settlements. Katy Mee, British Geological Survey.

respond is surpassed, but in pre- and post-disaster risk reduction decisions, local government is expected to play a dominant role.

From 1961 up until the volcanic crisis, the local government in Montserrat enjoyed very high levels of autonomy from the UK. The 1960s saw a period of decolonisation in the Caribbean and although Montserrat's leaders chose to remain part of Britain, the island became self-governing with the formation of a locally elected ministerial government. From then on, Montserrat, like the Turks and Caicos, Cayman Islands and Anguilla, was treated as a quasiindependent state. A new constitution in 1989 set the parameters for these governance arrangements, giving the local government close to full autonomy over decisionmaking within the territory. The governor of Montserrat, a UK government representative and civil servant in the Foreign and Commonwealth Office (FCO), was responsible for defence, external affairs and internal security but performed mainly ceremonial roles. The local government meanwhile carried out most normal areas of government activity such as provision of health and education, policing and land-use planning with relatively little interference from the UK government, requiring minimal budget support and even developing some infrastructure projects independently (Clay et al. 1999).

In terms of vertical coordination, a set of 'ad-hoc' and 'personalised' governance arrangements had evolved between the UK and its Caribbean Overseas Territories before the volcanic crisis. These reflected neither a sense of shared sovereignty (as in the French Caribbean) nor negotiated autonomy (as in the Dutch Caribbean), but rather an assumption by the UK government that these territories would become independent (Hintjens and Hodge 2012: 202). Even the constitution created ambivalence, recognising Montserrat's separateness, but maintaining the UK's constitutional power to invoke emergency orders and intervene directly in domestic affairs.

In-line with this broad level of independence before the volcanic crisis, Montserrat was also free to design and implement its own policies in response to perceived disaster risks; however, limited local capacity to identify and analyse risk was only part of the problem. Concentration of political power within a few wealthy families, party politicking and personalised politics, common to 
other island states (Skinner 2002) meant that policies were geared towards favouring interest groups not serving the needs of the most vulnerable.

Like many of its Caribbean neighbours, Montserrat is prone to a range of geological and hydro-meteorological hazards and yet risk management knowledge was not well developed and had not been incorporated into mainstream development (World Bank 2002). Knowledge of volcanic risk was extremely low amongst local politicians and UK government representatives on island despite the publication of the Wadge and Isaacs report (1986), which had been commissioned by the Pan Caribbean Disaster Preparedness and Prevention Project (CDPPP). The report warned of volcanic activity and the potential impact that an eruption would have to the island's capital, Plymouth. An early version of the report was discussed with the Permanent Secretary in the Chief Minister's office, yet there was no long-term planning for a volcanic eruption (Shepherd et al. 2002). Many explanations have been offered for this omission, including a lack of previous experience with volcanic eruptions and the impenetrability of the scientific language, both of which meant that it was difficult for policy-makers to take the findings of the report seriously; as well as limited resources and the more immediate focus of dealing with hurricanes (interviews, local and UK government officials, Montserrat, 2-4 October 2012).

In 1989, Hurricane Hugo hit the island leaving 11 dead and over 3,000 homeless, as well as causing substantial damage to approximately 85 per cent of homes and to a number of the storm shelters (Berke and Wenger 1991). A Hurricane Preparedness Scheme had been in place since 1980, but Hurricane Hugo revealed serious weaknesses in planning, including poor emergency shelter construction and lack of maintenance. Moreover, the risk control measures that were in place for this type of hazard, including local development regulations and inspection and enforcement procedures, had not been effectively implemented, and the housing stock was not designed using storm-resistant construction techniques. Unable to respond to the crisis with local resources, a state of emergency was declared and day-to-day control of the island passed away from the locally-elected Chief Minister to the FCO (Skinner 2006: 57). The UK government took over emergency management efforts and the support was well received ( $£ 3 \mathrm{~m}$ in emergency aid and $£ 16 \mathrm{~m}$ in long-term reconstruction) promoting a quick material recovery and allowing Montserrat to achieve a budgetary surplus by 1995 (Clay et al. 1999).

Hurricane Hugo prompted a temporary alteration in the prevailing governance arrangements, with the local government losing decision-making autonomy and the UK becoming directly involved in local affairs. Montserrat is a contingent liability for the UK government, so when local capacity to respond was surpassed, the UK recognised its responsibility to intervene and assist the islanders (Hintjens and Hodge 2012). Lack of planning and heavy dependency of foreign assistance led to a loss of control on the part of Montserrat authorities' (Berke and Wenger 1991: 77), but this was not permanent and six months after the hurricane, Montserratian authorities were exerting substantial control over the recovery process and development plans.

Abrupt social events allow hitherto marginalised issues to get on the agenda, by opening up 'policy windows' and creating spaces for policy reform (Kingdon 1995). In the same way, major disasters can act as 'focusing events' by bringing the failures of existing disaster policies to the attention of the public and policy makers, opening up policy windows for DRM reform (Birkland 2006). Hurricane Hugo made it clear to local authorities that a more coordinated effort was needed to prepare for and respond to extreme events and in 1994 a National Disaster Action Plan was drawn up and an Emergency Operations Centre (EOC) established in 1995. However, for the reasons described above a volcanic eruption was not on the political radar either for inclusion in the plan or reconstruction efforts after Hurricane Hugo. Indeed, the $£ 16$ million investment in reconstructing Plymouth, building a new hospital and housing, would have acted as a major disincentive to investing elsewhere even if volcanic risk had been taken seriously. As such, reducing risk to hurricanes in the post-disaster reconstruction efforts locked Montserrat in to high exposure to volcanic risk and a development trajectory that would prove difficult to alter in the face of an abrupt change in the volcanic hazard.

Prior to the volcanic crisis Monserrat was poorly integrated in regional and international risk governance systems. There was no formal mechanism through which Montserratian authorities could access resources or advice on disaster scenarios, potential impact and risk reduction options, although in fairness the international community as a whole understood little about the social or political sources of disaster risk in 1995. International and regional organisations at that time were promoting scientific, engineering and bureaucratic (or 'technocratic') solutions to disaster problems (Hewitt 1995; Cannon 1994). The Caribbean Disaster Emergency Response Agency (CDERA), set up in under the Caribbean Community and Common Market (CARICOM) in 1991, was, as its name suggests, a response-focussed agency with objectives of coordinating relief efforts, channelling aid from NGOs and other governments, mitigating the immediate consequences of disaster and improving disaster response capacity amongst participating states. As such, it provided little guidance as to how to assess and manage risk. Montserrat could not expect much in the way of technical support or guidance from the UK government either, as it did not have a DRM 
plan of its own at that time - the Civil Contingencies Act was not brought into force until November 2005. Overall, the lack of coherence across knowledge systems, resulted in a limited consideration of any hazards in development policies and plans. In particular, it made Montserrat highly susceptible to the unknown risks associated with the Soufrière Hills volcano.

\section{During the crisis}

Emergency management during the crisis has been characterised as unplanned, reactive and short term (Clay et al. 1999). Lack of preparedness meant that 'actions taken by the UK Government and the Government of Montserrat were driven stepwise by events in the volcanic escalation' (Kokelaar 2002: 1). Unlike Hurricane Hugo, where Montserrat's independence from the UK remained largely unaltered despite huge investments in reconstruction, the volcanic crisis brought about an abrupt realignment of vertical governance arrangements, with the UK government's position towards this overseas territory shifting radically towards greater intervention as the crisis unfolded. Even as Montserrat moves beyond recovery into processes of longer-term development, central-local relations have not returned to their pre-eruption state.

The EOC was the key local government entity managing the response to the volcanic eruption (Clay et al. 1999). Though a nominally 'local' institution led by the chief minister's office, the EOC is activated by the governor who on 3 April 1996 declared a state of emergency, thus rendering the EOC subservient to the governor's office and ultimately the FCO. At the beginning of the crisis the EOC made some decisions about planning and coordination of evacuations, supplies and shelters; but once the state of emergency was declared it no longer made any substantive decisions without the governor's consent. In small face-to-face societies 'people take on a number of roles and might interact with each other in different capacities at different times of the day [and] [t]his can make communication very difficult' (Skinner 2002: 307). During the crisis these norms of communication were suddenly altered by changes in the already complex functions of different actors, often creating tension - for example between the chief minister and the governor.

In addition to this shift in decision-making authority, the capacity of the EOC to make decisions regarding emergency response was tested and found wanting, as decisions during the crisis became more complex. In shelter management, for example, the EOC had no special expertise or sensitivity to the importance of engaging people in decisions (Clay et al. 1999: 70). Moreover, as people (and particularly the middle class) began to leave the island as the crisis intensified, local management capacity was further eroded.
The volcanic crisis was marked by a lack of contingency planning or strategy for how the FCO and the then the Overseas Development Agency (ODA) would manage a complex and long duration emergency in an overseas territory: 'Ad-hoc arrangements had to be put in place and this was done reactively as the eruption progressed' (Clay et al. 1999). The strategy adopted was to react to changing hazard levels as they were identified but this lack of planning, coupled with low levels of communication and community consultation, meant that UK and 'local' ideas about how to manage emergency response often diverged.

Weaknesses in planning were also partly due to poor horizontal coordination between the FCO, which delegated advice on external affairs, civil order and financial matters to the Dependent Territories Regional Secretariat (DTRS) in Barbados, set up in 1993, and ODA. Each had responsibilities and roles to play in an emergency situation but there were some unclear areas of responsibility within this complex set of horizontal institutional arrangements, resulting in a fragmentation in authority (Clay et al. 1999: 16). Prior to the crisis, Montserratian authorities had become accustomed to dealing only with the DTRS but as the crisis evolved, other departments and individuals would become more directly involved in emergency aid, splitting the decision-making responsibility and resources across branches of government. This 'bizarre situation', as it was referred to by journalist Polly Pattullo (2000: 137), was compounded by insufficient mechanisms for interdepartmental coordination of responsibilities in London (Clay et al. 1999: 16). In addition, aid coordination was complicated by donations coming in from a range of sources including bilateral aid from CARICOM countries, regional/multilateral aid from the Caribbean Development Bank (CDB), the European Commission Humanitarian Office (ECHO), and from NGOs. Montserrat was not short of emergency relief, according to local residents, but there were not enough trained people to handle it and this, along with delays at customs because packages were not properly labelled, slowed down the process (focus group discussions, 27 September 2012).

Trust between the state and society can be caused and aggravated by low levels of formal public consultation on as well as public willingness to participate in - decisions regarding emergency management (Wilkinson 2012). The emergency aid programme in Montserrat was implemented with little local consultation creating tensions between UK and local authorities, a deepening sense of insecurity amongst residents and growing mistrust between local stakeholders and UK government. As tents, cots and army rations were distributed, the inappropriateness of many of the supplies became apparent (interviews and focus groups, various, 28 September - 3 October 2013). Examples included bringing in pit latrines, which 
had never before been used on the island, and tents to be used as shelters, which would not withstand tropical storms and were inappropriate for the heat; all of which could have been avoided by consulting local authorities. Conversely, although citizens were able to express their views on both local and UK government handling of affairs through radio programmes, they were reluctant to go to town meetings. Hence, formal channels of social participation in decisionsmaking were very limited (interviews, local government officials and residents, 1 and 3 October 2012).

Lack of coherence between local and UK authorities over policy direction also contributed to growing mistrust. The local government preferred a 'wait and see' approach during the early phases of the emergency, assuming less serious impacts from the eruption, which resulted in deferral of UK-funded public housing construction in the north. The UK government, on the other hand, preferred to plan for the worst case, because of its ultimate responsibility for Montserrat (Clay et al., 1999: 54). This included drawing up a plan for the complete evacuation of the island, known as Operation Exodus. Operation Exodus had existed since the early days, but did not become public knowledge until May 1998, which generated rumours of 'relocation schemes' and plans by the UK government to 'de-populate the island' (interviews, local residents, 3 October 2012). The UK government was unlikely to have had any genuine desire to empty the island but the lack of a public communications strategy on shelters, evacuations and recovery plans had negative repercussions with Montserratians commonly expressing the view that the UK Government wanted us off the island' (interview, local resident, 3 October 2012).

Coherence in emergency management was complicated by the various vertical lines of communication that existed between different UK departments and local authorities and between the scientists on and off the island and UK and local authorities. In particular, the volcanic crisis highlighted the lack of local capacity to translate and communicate scientific information and this had repercussions for awareness of risk amongst local government officials and the public:

There was not a systematic analysis of scientific advice and policy-makers did not know what questions to ask... The Wadge Report was a perfect example of that: no one took any notice because it was not translated into practical advice (interview, UK government official, 2 October 2012).

From a local government perspective, clearer messages were needed and expected to help interpret volcanic hazard information, as one local government official explained (interview, local government official, 4 October 2012):
We had little experience with scientists. With hurricanes they are more hands off; they can show you on a computer and it is easier to understand. With a volcano it is difficult to see anything on which to base a decision, plus the scientists kept saying 'this is not an exact science.' In an effort to be cautious they actually reduced their own credibility and the public started to doubt.

The failure to articulate and coordinate policy direction also delayed reconstruction efforts and crucially, the decision to invest in the north and hence drastically reduce levels of volcanic risk on the island. The UK had put money into rebuilding Plymouth and continued to see it as the island's capital, and for this reason the Department for International Development (DFID) was reluctant to start buying up land in the north and building houses there (Clay et al. 1999). More broadly, the UK government was waiting for the volcano to stabilise before re-investing in the island's infrastructure, and at the same time, Montserratian authorities wanted to avoid sending out the wrong signals and were keen to maintain a 'business as usual' atmosphere to keep people on the island and keep the economy going (Skinner 2002). This may explain why it did not put more pressure on the UK government or ask for money to start building in the north; but the result was that two years after destruction of Plymouth, over 300 people were still living in temporary shelters (Haynes et al. 2008; Skelton 2003).

Despite complex organisational structures and unclear mandates, coordination of emergency management did improve as the crisis progressed. The administration of shelters improved for example when the UK government responded to complaints about aid in 1996 by introducing a food voucher scheme. In 1997, the vouchers were replaced by cheques as a pragmatic response to pressure for more flexibility, so people could use the income to pay other expenses such as rent (focus groups, various, 28 September - 3 October 2013). This also reduced the heavy administrative burden of the voucher scheme (Clay et al. 1999).

\section{After the volcanic crisis}

It is difficult to identify the exact point at which emergency management ended and longer-term recovery planning began, as recovery has not been a geographically evenly distributed phenomenon, with 'different areas of the island... in different stages of the recovery process' (Rozdilsky 1999: 6). Similarly, it is hard to identify the time when the people of Montserrat accepted and began to plan for a new future in the north of the island. Certainly, the 19 deaths on 25 June 1997 were 'a game changer' (interview, UK government official, 2 October 2012). 
A major turning point relates to the type of support Montserrat received from the UK. From late 1997 onwards, emergency aid was increasingly outweighed by budget support and substantial capital investments to re-establish basic services, develop infrastructure and provide incentives and an enabling environment for private investment and longer-term development. From 1997 to 2012, DFID spent $£ 325$ million on technical assistance, budgetary support and capital investments, representing 50 per cent of the total spent on Overseas Territories during that period. Six capital investment projects alone (an airport, roads, water, power and education) involved an investment of over $£ 34$ million (ICAI 2013). However, the scale of this investment came at the price of heavy reliance on the UK, and although the local government is keen to avoid long-term dependency and achieve self-sufficiency but there is no realistic plan for doing so. The 2011 Strategic Growth Plan, for example, creates 'no overall picture of self-sufficiency for the island' (ICAI 2013: 8). A reliance on the UK for capital is compounded by the fact that Montserrat cannot access development finance from other sources. It is not eligible for loans from the World Bank or International Monetary Fund, although it receives some funds from the EU and CDB - $£ 4.8$ million from 2012 to 2015 , but this merely supplements the $£ 24$ million committed by DFID for the same period (ICAI 2013).

A change of government in the UK in May 1997 had far-reaching consequences for risk management in Montserrat, with the UK government at senior level taking more of an interest. The Montserrat Action Group was formed and the then Secretary of State for International Development Claire Short established a joint DFID-FCO review of off- and on-island options, and $£ 6.5 \mathrm{~m}$ was allocated by the UK government for development in the north. Coordination of recovery efforts improved thanks to a clarification of mandates in London within one department - the Conflict and Humanitarian Affairs Department of DFID - which was made responsible for coordination of all financial aid and equipment to Montserrat. However, this had the impact of separating UK development and foreign policy, with Montserrat's governor reporting to the FCO and the Aid Office reporting to DFID, essentially separating safety from funding.

Despite its financial dependency on the UK, improvements in DRM policy and organisational structures owe more to Montserrat's insertion in the regional disaster risk governance system. The new unit in government in 1997, now called the Disaster Risk Management Coordination Agency (DMCA), set up to coordinate DRM activities, and the Disaster Preparedness and Response Act of 1999, were based more on examples from around the Caribbean than the UK disaster management system. CDERA (which later became the Caribbean Disaster Emergency Management Agency (CDEMA) in 2009) adopted a comprehensive disaster management approach and national emergency management offices across the Caribbean have followed suit. These strategies also reflect the language and priority areas of the Hyogo Framework for Action 2005-2015; demonstrating the influence that international policy has had on regional risk management.

Integration in the regional risk governance system deepened in 1999, when the Montserrat Volcano Observatory Act was passed, bringing it under local legislation and encouraging 'collaborative links with regional and extraregional centres of expertise in scientific disciplines relevant to monitoring volcanic activity' (1999, Art.8). It was now seen as a locally owned institution (interview, UK government official, 2 October 2012). Montserrat also began to receive advice and support from CDEMA, as one of 18 participating states and was included in the Action Plan 2011-2012 for the Caribbean, promoted by the disaster preparedness programme of the European Commission's Humanitarian Aid and Civil Protection Directorate General (DIPECHO). Montserrat's Sustainable Development Plan 2008-2020 now reflects a comprehensive disaster management mentality, with a Strategic Goal on environmental management and disaster mitigation that emphasises governance structures, training and education on DRM and building response capacity at all levels.

Even more encouragingly DRM is now seen to be an integral part of the development process, at least on paper. Local government authorities recognise that disasters can lead to major disruptions to the island's developmental agenda (Government of Montserrat 2005). The Montserrat Corporate Plan 2003-2006, health, water and education sector plans all included DRM elements, although these mainly focussed on streamlining disaster preparedness and response. In 2003, for example, the Ash Clearing Assistance Project concentrated on reducing air pollution and health hazards in the environment after the volcano dome collapse. Local ownership over emergency response was clearly demonstrated at this time: the Montserrat government declared the disaster and activated the emergency operations centre, which then acted as the coordination body for response and relief efforts.

Notwithstanding these improvements however, decisionmaking authority on island and the coordination of DRM activities is still limited by the absence of an inclusive DRM plan. As of October 2012, the Disaster Management Plan was still not finalised and had only been updated in an ad-hoc manner by the DMCA director. Hence the content of the plan and allocation of responsibilities remains unclear to other government officials (interviews, local government officials, 3-4 October 2012). The DMCA is an operational not regulatory agency with a mandate to 
prepare for emergencies, not reduce levels of risk in society and so can only play a limited role in strengthening local DRM capacity on-island. As one local government official commented:

Institutions are stronger, but high staff turnover and lack of technical experience mean that an effective disaster response in the future will require quick funding and external support. The Government of Montserrat will be able to respond in a limited way for a week or two but will need financial support and technical assistance (interview, local government official, 3 October 2012).

By the end of 1997 the north was deemed safe for occupation but people were still living in shelters. A Sustainable Development Plan was produced identifying health, education and housing investments needed for economic and social recovery, but many of these investments were undertaken with only a short-term focus: the hospital was upgraded at the St John's site, not rebuilt; an emergency jetty was built at Little Bay instead of a harbour; and only a temporary government headquarters were set up in Brades (Sword-Daniels et al. 2013). For many, it was not until 1999 that the emergency phase really ended. Eruptive activity continued, but a new governance regime was beginning to emerge with a vision of the island's future development. This 'co-governance' regime would continue to dominate central-local relations in Montserrat to the present day. The local government began to take the lead on day-to-day management functions, such as the procurement and management of development projects and some control over spending decisions, but with strong oversight and financial control from the UK. Montserrat regained some autonomy with respect to the crisis period, but compared with the pre-crisis situation, economic dependency remained high:

\section{DFID keep changing the rules of the game, including} greater scrutiny of expenditures, increasing limits to what officers can approve now (compared to 1995). All this affects our ability to respond quickly to people's needs (interview, UK government official, 3 October 2012).

Greater coherence between UK and local risk perceptions and DRM activities can be observed from 2001 onwards with the development of a strategy to sustain the on-island community and promote long-term investment in the north of the island (Clay et al. 1999: 13). By restricting access to proximal areas (the boundaries of which have changed over time (Aspinall et al. 2002)) and investing in basic and road infrastructure, housing and services in the north, levels of exposure to pyroclastic flows and lahars have all been dramatically reduced (Sword-Daniels et al. 2013). For the Montserrat Government these decisions marked an important turning point in the recovery process:

In 2001 the economy began to recover and economic plans were made, based on scientific advice. The Scientists said that the far north was of low negligible risk. Once that was said they set the foundations for serious thinking about investment for those who stayed. They realised it would have to be in the north (interview, local government official, 3 October 2012).

There was no formal public consultation process to establish how different actors viewed volcanic risk on the island (Haynes et al. 2008), however, perceptions of risk appear to have been broadly aligned at this point with residents beginning to consider the north their permanent home (interviews, local residents, 1-3 October 2012). Many had already left the island after by the Boxing Day collapse in 1997 and facilitated by relocation packages offered in 1998, but even for those that stayed and had lost their houses, land and jobs, the north did not represent an 'acceptable option' in terms of levels of risk and livelihood options until housing reconstruction began (interview, UK government official, 2 October 2012). This perception of the south being dangerous (approximately 60 percent of the island) and the north being safe for habitation was broadly in line with the scientific assessments, through which areas were established as exclusion zones - some permanently, and others in accordance with the level of volcanic activity. Despite informal reports of people entering the permanent exclusion area (Zone V) without permission, the current general perception amongst islanders is that this area will continue to be highly exposed to volcanic hazards and they will never be able to return (interviews and focus groups, various, 28 September - 3 October 2013).

In the transition from recovery to longer-term development, greater vertical coherence in development planning has emerged. This owes much to harmonisation across departments in the UK, with ODA being upgraded to ministry status and re-named DFID, with overall responsibility for the aid budget. A team of programme officers for Montserrat was created within DFID and on island (a resident lead, an infrastructure adviser and two programme officers) (ICAI 2013). Forced on to the political agenda in the UK by the volcanic crisis, these changes -outlined in the 1999 White Paper Partnership for Progress and Prosperity and 2002 British Overseas Territories Act- have had important implications for inter-governmental mandates: any laws adopted by the UK or through the European Union, are now applicable to Montserrat. This includes 
more stringent EU environmental laws. The Act has brought about increased consultation between political cadres of territories and the UK government, and a more proactive dialogue has opened up (interviews, UK and local government officials, 1-2 October 2012).

The volcanic crisis had uncovered some of the inherent contradictions in the autonomous system of governance in Montserrat, but it also prompted UK and local authorities to consider their own levels of risk tolerance and responsibilities for reducing exposure. A tacit alignment of UK and local government risk perceptions was established in 1999 and endorsed through the definition of an exclusion zone and subsequent investment in the north. Yet more recent studies suggest that these formal notions of tolerable risk may not be shared by the local population or even the local government (Haynes et al. 2008). Exposure to high-impact events such as pyroclastic flows has been dramatically reduced through officially prescribed norms intended to reduce risk (relocation and establishing exclusion zones), but the north of the island had been affected by ash fall and acid rain until recenly, representing a low-level, intermittent but widespread risk that is given low consideration in development planning. Ash fall presents health risks and asthma sufferers in particular have reported suffering respiratory problems from heavy ash fall (interviews, local residents, 1 to 3 October 2012). Infrastructure built during the recovery period has also been affected and needs constant cleaning, replacement and repair. Most buildings (and homes) have tropical slatted windows, which allow ash to enter buildings because they cannot be properly sealed (Sword-Daniels et al., 2013).

The negative impacts of relocating people in the north of the island and of the social upheaval of Montserratians moving to the UK should not be overlooked. Most Montserratians on the island today, are worse off economically that before the eruption. Farming activities are less lucrative and farmers are reluctant to invest as they do not have security of tenure and are aware of the threat of future ash fall and acid rain (Halcrow Group and the Montserrat National Assessment Team 2012). Land shortages in the north have meant that new houses have been erected in unsafe and unsuitable locations such as ravines (Hicks and Few, 2014). Although resettlement has reduced exposure to volcanic hazards, these policies have created new vulnerabilities for the island population that may be more tolerable than volcanic hazard exposure for now, but this may not always be the case.

There are instances of individuals not subscribing to official rules, which suggests that levels of risk tolerance vary and are not static. People entering the exclusion zone for livelihood reasons, such as tending to crops and illegal scrap metal collecting, as well as those building too close to the exclusion zone, are examples of this. Expatriate residents continue to live in Old Towne, which can become part of the exclusion zone with heightened volcanic activity, and have expressed their reluctance to evacuate and lack of confidence in the alert levels issued by the MVO and temporary evacuations decisions (interviews, local residents, 3 October 2012). Nearby Salem has a secondary school and a primary healthcare clinic and is home to a growing immigrant population and an ad-hoc business district (Sword-Daniels et al. 2013). Rental housing is cheaper in this area and new arrivals appear to be less aware of the risks associated with volcanic activity than Montserratians (interviews, local residents and local government, 1 to 3 October 2012). Overall, the view that the future of the island is in the north appears not be as unanimous as official views and recent patterns of infrastructure investments suggest.

Another factor suggesting that local authorities may not entirely endorse the idea of development in the north is the temporary nature of much of the island's vital infrastructure. Sword-Daniels et al. (2013) note that many of the buildings and essential services that were put up during the recovery period were not permanent structures. These facilities have been upgraded incrementally over time but the perception of sites as temporary has in some cases obstructed funding leaving some buildings in an inadequate state. These 'quick fixes' need to be re-addressed to enable further progress towards development goals.

\section{Discussion}

The disaster risk governance regime in Montserrat has undergone a radical shift as a result of the volcanic crisis of 1995-1997 and alterations in central and local perceptions of volcanic risk. Essentially, a longer-term view of risk has been adopted by UK and local authorities, scientists and local communities, and this has brought with it substantial investments in safer locations further north and a belief that the future of the island is in the north. DRM in Montserrat is no longer concerned with the circumstances under which a return to south will be possible or how to make lives and livelihoods safer in former settlements. The longer term view of risk management being taken and new investments being made in safer locations further from the volcano, represents an important shift in the risk governance system (see Table 2).

A transformation towards greater vertical coherence has also taken place but is not complete, and there are signs that local and external-scientific assessments of volcanic risk in Montserrat are diverging. In particular, scientists and UK government officials have raised concerns about increasing settlement in areas close to the exclusion zone plus the low consideration given to ash fall in development planning (interviews, UK government officials and scientists, Montserrat, 2-4 October 
2012). These comments and trends collectively suggest that the tolerable level of risk for local residents is higher in some cases than that established by UK and Montserratian authorities. Similarly, international development agencies have expressed concern that public awareness of hazards other than volcanoes needs to be improved. According to a review of disaster risk management capacity in Montserrat carried out by UNDP (2010), the focus of DRM activities is too often related to the Soufrière Hills volcano, with insufficient emphasis on a multi-hazard approach.

These local perceptions of risk and the cognitive processes through which risks are deemed insignificant or adequately controlled by individuals and groups need to be explored further and contrasted with external and scientific judgements. Calculations of tolerable risk are not static and the analysis presented above demonstrates how both new people coming into a volcanic area and the passing of time may change 'local' perceptions of risk. The Montserrat case does however suggest that transformational shifts in disaster risk governance can only occur when tolerable levels of risk are agreed on by stakeholders and this will require high levels of horizontal as well as vertical and coherence.

In analysing continuities and discontinuities in Montserrat's disaster risk governance system from the late 1980s to the present day, alterations in the governance system can be observed on two occasions: in the aftermath of Hurricane Hugo and during the volcanic crisis period. For both events, abrupt changes in levels of disaster risk and limited local capacity to respond led to greater external interference in local DRM decisions. Although Hurricane Hugo was a high impact event, the hazard subsided quickly and these alterations were temporary. The volcanic eruption, on the other hand, occurred over a long period of time and produced more permanent changes in the disaster risk governance regime and in the island's governance system more broadly. The sharp and sustained rise in the level of volcanic risk combined with a weak response from local and UK authorities led to a sustained reduction in local autonomy but also an increase in vertical coherence and when levels of risk declined and post-disaster recovery ended these new configurations did not return to their pre-crisis state.

This transformation may not prove to be irreversible, although there could be a latent 'tendency towards dependency' in Montserrat common to all UK overseas territories (Pattullo 2000; Skinner 2002). For critics of UK colonialism these territories 'will always struggle to develop and will always be dependent upon other places and people' (Skinner 2002: 316). One aspect of the shift in risk governance in particular that may be permanent is that of increased vertical coherence. Although local capacity to assess risk and implement risk reduction measures is still limited by lack of human and technical resources, Montserrat is now better integrated into a regional disaster risk governance system that can offer this support and advice. This is unlikely to change.

\section{Conclusions}

This research draws a number of conclusions about volcanic crises and regime change in Montserrat of relevance to multi-tiered governance regimes elsewhere and to different hazardous contexts. The examples of Hurricane Hugo and Soufrière Hills both suggest that crises brought about by sharp increases in the level of risk are likely to provoke temporary alterations in central-local relations, and in particular a sharp decline in local autonomy over DRM decisions. This intervention by external actors can have both negative and positive consequences for disaster risk management, creating dependency but also enhancing vertical coherence, offering opportunities for learning and capacity building.

Table 2 Nature and processes of disaster risk governance in Montserrat

\begin{tabular}{|c|c|c|c|c|}
\hline \multirow{2}{*}{$\begin{array}{l}\text { Change in disaster } \\
\text { risk governance system }\end{array}$} & & \multicolumn{3}{|l|}{ Phases of volcanic risk } \\
\hline & & Pre-crisis & During crisis & Post-crisis \\
\hline \multirow[t]{2}{*}{ Nature of change } & $\begin{array}{l}\text { (a) Dispersion of } \\
\text { decision-making }\end{array}$ & $\begin{array}{l}\text { (a) Little UK interference in } \\
\text { development decisions. }\end{array}$ & $\begin{array}{l}\text { (b) Scaling-up of UK intervention } \\
\text { in response to weak local capacity. }\end{array}$ & $\begin{array}{l}\text { (a) New co-governance regime with } \\
\text { low levels of local autonomy. }\end{array}$ \\
\hline & $\begin{array}{l}\text { (b) Vertical } \\
\text { coherence }\end{array}$ & $\begin{array}{l}\text { (b) Poorly articulated DRM } \\
\text { policies and little } \\
\text { coherence. }\end{array}$ & $\begin{array}{l}\text { (b) Problems with policy coherence } \\
\text { creating confusion over policy aims, } \\
\text { lack of confidence in government } \\
\text { and mistrust. }\end{array}$ & $\begin{array}{l}\text { (b) Greater vertical coherence on } \\
\text { DRM - e.g. linking up with other } \\
\text { scales (regional and EU). }\end{array}$ \\
\hline \multirow[t]{2}{*}{ Change process } & (a) Stability & $\begin{array}{l}\text { (a) Temporary shift to high } \\
\text { levels of external control } \\
\text { (after Hurricane Hugo). }\end{array}$ & $\begin{array}{l}\text { (a) Temporary shift to high levels of } \\
\text { external control. }\end{array}$ & $\begin{array}{l}\text { (a) Sustained shift to high levels of } \\
\text { external control. Irreversible shift to } \\
\text { greater vertical coherence. }\end{array}$ \\
\hline & (b) Extent & (b) Little change. & $\begin{array}{l}\text { (b) Incremental change to vertical } \\
\text { relations during crisis. }\end{array}$ & $\begin{array}{l}\text { (b) Transformation in decision-making } \\
\text { control. Incomplete transformation in } \\
\text { vertical coherence. }\end{array}$ \\
\hline
\end{tabular}


The Montserrat experience is atypical however and caution should be exercised in drawing lessons for other contexts. In particular, the relationship between the UK and its overseas territories is unique and different even from French and Dutch overseas territories in the Caribbean. Central governments elsewhere may not be so inclined to provide ongoing financial support to local governments after the recovery process is considered to have ended. Similarly, local governments with significant levels of autonomy in decentralised and particularly federal systems of governance elsewhere are likely to reject sustained central government interference in local affairs following a protracted crisis. Governance reform in Montserrat was the product of conflict, but ultimately compromise, and in other contexts consensus between central and local authorities on tolerable levels of risk may be harder to achieve. Notwithstanding these caveats, however, the transition to co-governance and the reframing of disaster risk that have taken place in Montserrat provide useful examples of how transformations can occur in disaster risk governance systems following high-intensity, long-duration volcanic events.

The experience of Montserrat also provides useful insights for volcanic islands elsewhere and small island states with disaster risks more generally. Small islands have few options for resettlement when significant parts of the territory are destroyed by a disaster, or when the decision is taken to move populations before a disaster to prevent loss of life. The benefits in terms of reducing disaster risk have to be weighed against loss of livelihoods for a significant proportion of the population, considerable social upheaval and often economic decline. Critical to the success and sustainability of these risk management decisions is the need for vertical coherence and dialogue between different scales of governance. In Montserrat this has been partly achieved through greater integration into the regional risk governance system and via the establishment of an economically dependent but politically autonomous system of co-governance with the UK. But unless communities are also engaged in risk governance decisions and consensus is built, this tacit agreement to pursue a low-volcanic-risk development model could come unstuck. Small islands with large risks can learn from the Montserrat experience. They can anticipate and plan for how these dialogues might take place in the event of a major disaster.

\section{Endnotes}

${ }^{a}$ For a more detailed discussion of complex social relations and personal politics of small societies as well as the dependency mentality of overseas territories ad former colonies see Skinner (2002).

${ }^{\mathrm{b}}$ The Montserrat workshop was run by the STREVA programme as part of a 'forensic' research process, from 25-29th September 2012.

\section{Additional file}

Additional file 1: A summarised chronology of events and decisions related to disaster risk governance.

\section{Abbreviations}

CARICOM: Caribbean Community and Common Market; CDB: Caribbean Development Bank; CDEMA: Caribbean Disaster Emergency Management Agency; CDERA: Caribbean Disaster Emergency Response Agency; CDPPP: Caribbean Disaster Preparedness and Prevention Project; DFID: Department for International Development; DMCA: Disaster Management Coordination Agency; DRM: Disaster risk management; DTRS: Dependent Territories Regional Secretariat; ECHO: European Commission Humanitarian Office; EOC: Emergency Operations Centre; EU: European Union; FCO: Foreign and Commonwealth Office; ODA: Overseas Development Agency; MVO: Montserrat Volcano Observatory; STREVA: Strengthening Resilience in Volcanic Areas..

\section{Competing interests}

I have not received reimbursements, fees, funding, or salary from an organization that may in any way gain or lose financially from the publication of this manuscript, either now or in the future.

I do not hold any stocks or shares in an organization that may in any way gain or lose financially from the publication of this manuscript, either now or in the future

I do not hold and am not currently applying for any patents relating to the content of the manuscript. I have not received reimbursements, fees,

funding, or salary from an organization that holds or has applied for patents relating to the content of the manuscript.

I have no other financial competing interests.

I do not have any non-financial competing interests (political, personal, religious, ideological, academic, intellectual, commercial or any other) to declare in relation to this manuscript.

\section{Acknowledgements}

The author would like to thank Edward Clay for early discussions on UKMontserrat relations, Richie Robertson, Barbara Carby and Peter Simmons for providing comments and suggestions on how to improve this paper and to three anonymous reviews who provided useful comments. Research was conducted under the STREVA project, funded by the NERC/ESRC Increasing Resilience to Natural Hazards in Earthquake-prone \& Volcanic Regions programme.

Received: 7 July 2014 Accepted: 18 December 2014 Published online: 24 January 2015

\section{References}

Alexander D (2002) Principles of Emergency Planning and Management. OUP, New York

Argyris C (1999) On Organizational Learning, 2nd edn. Blackwell, Oxford

Aspinall WP, Loughlin SC, Michael FV, Miller AD, Norton GE, Rowley KC, Sparks RSJ, Young SR (2002) The Montserrat Volcano Observatory: Its Evolution, Organization, Role And Activities. In: Druitt TH, Kokelaar BP (eds) The eruption of Soufrière Hills Volcano, Montserrat, from 1995 to 1999, vol 21. Geological Society, London, Memoirs., pp 71-91

Barnes P (2002) Approaches to community safety: risk perception and social meaning. Austr J Emerg Manage Autumn 2002:15-23

Bené C, Godfrey Wood R, Newsham A, Davies M (2012) Resilience: new utopia or new tyranny? Reflection about the Potentials and Limits of the Concept of Resilience in Relation to Vulnerability Reduction Programmes. IDS Working Paper 2012 (405). Institute of Development Studies, Brighton

Berke P, Wenger D (1991) Montserrat: Emergency Planning, Response and Recovery Related to Hurricane Hugo. Texas A\&M University, Hazard Reduction and Recovery Center, College Station, Texas

Birkland TA (2006) Lessons of Disaster: Policy Change after Catastrophic Events, American Governance and Public Policy Series. Georgetown University Press, Washington DC

Cannon T (1994) Vulnerability Analysis and The Explanation Of 'Natural' Disasters. In: Varley A (ed) Disasters. Development And Environment. John Wiley, Chichester, pp 13-30 
CARICOM (2009) National Census Report. Montserrat, CARICOM Secretariat, Georgetown, Guyana

Christoplos I, Mitchell J, Liljelund A (2001) Reframing risk: the changing context of disaster mitigation and preparedness. Disasters 25(3):185-198

Clay EB, Barrow C, Benson C, Dempster J, Kokelaar BP, Pillai N, Seaman J (1999) An Evaluation of HMG's Response to the Montserrat Volcanic Emergency. Department for International Development, London

Cutter S, Barnes L, Berry M, Burton C, Evans E, Tate E, Webb J (2008) A place-based model for understanding community resilience to natural disasters. Glob Environ Chang 18(4):598-606

Donovan A, Oppenheimer C (2013) Science, policy and place in volcanic disasters: insights from Montserrat. Environ Sci Policy 39:150-161

Donovan AR, Bravo M, Oppenheimer C (2012) Co-production of an institution: Montserrat Volcano Observatory and social dependence on science. Sci Public Policy 40(2):171-186

Gaillard JC (2008) Alternative paradigms of volcanic risk perception: the case of Mt. Pinatubo in the Philippines. J Volcanol Geotherm Res 172(3-4):315-328

Gibson C, Ostrom E, Ahn TK (2000) The concept of scale and the human dimensions of global change: a survey. Ecol Econ 32:217-239

Government of Montserrat (2005) Montserrat National Report And Information On Disaster Reduction. Paper presented at the World Conference on Disaster Reduction. Kobe, Japan

Gregg CE, Houghton BF, Johnston DM, Paton D, Swanson DA (2004) The perception of volcanic risk in Kona communities from Mauna Loa and Hualalai volcanoes, Hawaï. J Volcanol Geotherm Res 130(3-4):179-196

Haynes K, Barclay J, Pidgeon N (2008) Whose reality counts? Factors affecting the perception of volcanic risk. J Volcanol Geotherm Res 172:259-272

Heijmans A (2001) Vulnerability: A Matter of Perception. Disaster Management Working Paper 4/2001. Benfield Greig Hazard Research Centre, UCL, London

Heinelt H (2002) Achieving Sustainable And Innovative Policies Through Participatory Governance In A Multi-Level Context: Theoretical Issues. In: Heinelt H, Getimis P, Kafkalas G, Smith R, Swyngedouw E (eds) Participatory Governance In Multi-Level Context: Concepts And Experience. Leske + Budrich, Opladen, pp 17-32

Halcrow Group and the Montserrat National Assessment Team (2012) Participatory Poverty Assessments. Halcrow Group Limited, London

Hewitt K (1983) The Idea Of Calamity In A Technocratic Age. In: Hewitt K (ed) Interpretations Of Calamity: From The Viewpoint Of Human Ecology. Allen and Unwin, Boston MA, pp 3-32

Hewitt K (1995) Regions of Risk: A Geographical Introduction to Disasters. Longman, Harrow

Hicks A and Few R (2014) Trajectories of social vulnerability during the Soufrière Hills volcanic crisis. Journal of Applied Volcanology (in press)

Hintjens H, Hodge D (2012) The UK Caribbean Overseas Territories: governing unruliness amidst the extra-territorial EU. Commonwealth Comp Polit 50(2):190-225

ICAI (2013) DFID's Support To Capital Projects in Montserrat. Independent Commission for Aid Impact, London

Kingdon J (1995) Agendas, Alternatives and Public Policies, 2nd edn. Harper Collins, New York

Kokelaar BP (2002) Setting, chronology and consequences of the eruption of Soufrière Hills Volcano, Montserrat (1995-1999). Geol Soc London Memoirs 21:1-43

McGinnis M (2000) Polycentric games and institutions: readings from the Workshop in Political Theory and Policy Analysis. University of Michigan Press, Ann Arbor Ml

Ostrom V (1997) The meaning of democracy and the vulnerability of democracies. University of Michigan Press, Ann Arbor MI

Ostrom E, Burger J, Field CB, Norgaard RB, Policansky D (1999) Revisiting the commons: local lessons, global challenges. Science 284:278-282

Pahl-Wostl C (2009) A conceptual framework for analysing adaptive capacity and multi-level learning processes in resource governance regimes. Glob Environ Chang 19:354-365

Paton D, Millar M, Johnston D (2001) Community resilience to volcanic hazard consequences. Nat Hazards 24(2):157-169

Paton D, Sagala S, Okada N, Jang LJ, Burgelt PT, Gregg CE (2010) Making sense of natural hazard mitigation: personal, social and cultural influences. Environ Hazards 9(2):183-196

Pattullo P (2000) Fire From The Mountain: The Tragedy Of Montserrat And The Betrayal Of Its People. Constable, London
Pelling M (2011) Adaptation To Climate Change: From Resilience To Transformation. Routledge, London

Pidgeon N, Hood C, Jones D, Turner B, Gibson R (1992) Risk Perception. In: The Royal Society (ed) Risk Analysis, Perception And Management: Report Of A Royal Society Study Group. The Royal Society, London, pp 89-134

Posner PL (1998) The Politics of Unfunded Mandates: Whither Federalism? Georgetown University Press, Washington DC

Ramalingam B, Jones H, Reba T, Young J (2008) Exploring The Science Of Complexity: Ideas And Implications For Development And Humanitarian Efforts, ODI Working Paper 285. Overseas Development Institute, London

Renn O (2008) Risk Governance: Coping With Uncertainty In A Complex World. Earthscan, London

Rozdilsky JL (1999) Disaster Recovery In An On-Going Hazard Situation On Montserrat: the July 20, 1999, Volcanic Dome Collapse, vol Quick Response Report \#21. Department of Resource Development Urban Studies Michigan State University, Michigan

Rozdilsky JL (2001) Second hazards assessment and sustainable hazards mitigation: disaster recovery on Montserrat. Nat Hazards Rev 2001:64-71

Schreyögg G, Sydow J (eds) (2010) The Hidden Dynamics Of Path Dependence: Institutions And Organizations. Palgrave Macmillan, Houndmills

Shepherd JB, Robertson R, Latchman J, Lynch L (2002) Precursory Activity to the 1995 eruption of the Soufrière Hills Volcano, Montserrat. Seismic Research Unit, The University of the West Indies, St. Augustine, Trinidad

Simmons P, Walker G (1999) Tolerating risk: policy principles and public perceptions. Risk Decis Pol 4(3):179-190

Skelton T (2003) Globalizing Forces And Natural Disaster: What Can Be The Future For The Small Caribbean Island Of Montserrat? In: Kofman E, Young G (eds) Globalization: Theory And Practice, 3rd edn. Continuum, London

Skinner J (2002) British constructions with constitutions: the formal and informal nature of 'Island' relations on Montserrat and Gibraltar. Soc Identities J Stud Race Nation Cult 8(2):301-320

Skinner J (2006) Disaster Creation In The Caribbean And Planning, Policy And Participation Reconsidered. In: Pugh J, Henshall Momsen J (eds) Environmental Planning In The Caribbean. Ashgate Publishing Limited, Aldershot, pp 53-72

Slovic P (1987) Perception of Risk. Science 236:280-285

Sword-Daniels V, Wilson TM, Sargeant S, Rossetto T, Twigg J, Johnston DM, Loughlin SC, Cole PD (2013) Consequences Of Long-Term Volcanic Activity For Essential Services In Montserrat: Challenges, Adaptations And Resilience. In: Wadge G, Voight B, Robertson R (eds) The Eruption Of Soufrière Hills Volcano, Montserrat From 2000 To 2010. Geological Society, London

Tanguy J-C (1994) The 1902-1905 eruptions of Montagne Pelée, Martinique: anatomy and retrospection. J Volcanol Geotherm Res 60(2):87-107

Tierney K (2012) Disaster governance: social, political and economic dimensions. Annu Rev Environ Resour 37:341-363

Twigg J (2004) Disaster Risk Reduction: Mitigation And Preparedness In Development And Emergency Planning. Overseas Development Institute, London

UNDP (2010) Disaster management capacity assessment report: Montserrat. United Nations Development Programme in Barbados and the. OECS, Bridgetown

Wadge G, Isaacs MC (1986) Volcanic hazard from Soufrière Hills Volcano Montserrat. A report to the Government of Montserrat and the Pan Caribbean Disaster Preparedness and Prevention Project. Department of Geography, University of Reading, Reading

Whitten SM, Hertzler G, Strunz S (2012) How real options and ecological resilience thinking can assist in environmental risk management. J Risk Res 15(3):331-346

Wilkinson E (2012) Why "small is beautiful" in municipal disaster risk reduction: evidence from the Yucatán peninsula, Mexico. Environ Hazards 11(2):155-171

Wilkinson E (2013) Disaster Risk Governance. In: Volcanic Areas: A Concept Note For Work Package 4 Of The Strengthening Resilience In Volcanic Areas (STREVA) Programme. Overseas Development Institute, London

World Bank (2002) Natural Hazard Risk Management. In: The Caribbean: Revisiting The Challenge, vol Report No. 24166-LAC, 1. Caribbean Group for Co-operation in Economic Development, World Bank, Washington D.C 